\title{
Review Article \\ Engineering Tendon: Scaffolds, Bioreactors, and Models of Regeneration
}

\author{
Daniel W. Youngstrom and Jennifer G. Barrett \\ Department of Large Animal Clinical Sciences, Marion duPont Scott Equine Medical Center, Virginia Tech, \\ 17690 Old Waterford Road, Leesburg, VA 20176, USA
}

Correspondence should be addressed to Jennifer G. Barrett; jgbarrett@vt.edu

Received 13 June 2015; Accepted 20 September 2015

Academic Editor: Franca Di Meglio

Copyright ( 2016 D. W. Youngstrom and J. G. Barrett. This is an open access article distributed under the Creative Commons Attribution License, which permits unrestricted use, distribution, and reproduction in any medium, provided the original work is properly cited.

\begin{abstract}
Tendons bridge muscle and bone, translating forces to the skeleton and increasing the safety and efficiency of locomotion. When tendons fail or degenerate, there are no effective pharmacological interventions. The lack of available options to treat damaged tendons has created a need to better understand and improve the repair process, particularly when suitable autologous donor tissue is unavailable for transplantation. Cells within tendon dynamically react to loading conditions and undergo phenotypic changes in response to mechanobiological stimuli. Tenocytes respond to ultrastructural topography and mechanical deformation via a complex set of behaviors involving force-sensitive membrane receptor activity, changes in cytoskeletal contractility, and transcriptional regulation. Effective ex vivo model systems are needed to emulate the native environment of a tissue and to translate cell-matrix forces with high fidelity. While early bioreactor designs have greatly expanded our knowledge of mechanotransduction, traditional scaffolds do not fully model the topography, composition, and mechanical properties of native tendon. Decellularized tendon is an ideal scaffold for cultivating replacement tissue and modeling tendon regeneration. Decellularized tendon scaffolds (DTS) possess high clinical relevance, faithfully translate forces to the cellular scale, and have bulk material properties that match natural tissue. This review summarizes progress in tendon tissue engineering, with a focus on DTS and bioreactor systems.
\end{abstract}

\section{Introduction}

Tendons connect muscle to bone, functioning in force translation and energy storage during movement [1]. Up to $80 \%$ of the dry mass of tendon is fibrillar collagen, and the specific mechanical properties of tendon are largely the result of type-I collagen organization within the extracellular matrix (ECM) [2]. Three $\alpha$-helical molecular $[\mathrm{Gly}-\mathrm{x}-\mathrm{y}]_{n}$ collagen strands form the triple helical foundation of tendon structure: these are quarter-staggered into banded microfibrils that are hierarchically arranged into secondary and tertiary bundles $[3,4]$. Collagen expression within tendon is regulated by a number of molecules including the transcription factor scleraxis $[5,6]$. Procollagen molecules undergo posttranslational modifications and their assembly is regulated by molecular chaperones [7, 8]. Type-III collagen is an important minority component of tendon ECM, and its elevated presence is associated with decreased fiber diameter [9] and postinjury repair [10]. Type- $\mathrm{V}$ collagen is also present in the core of fibrils and contributes to the structural arrangement of ECM more than its mechanical properties [11].

Partially a result of its characteristically low cellularity relative to other tissues, tendon matrix was once thought to be inert of metabolic activity [12]. However, much like the classic frameworks of bone and soft tissue remodeling (Wolff's Law and Davis' Law, resp.) [13], tendons dynamically respond to loading events [14], with different tendons exhibiting variations by function [15]. Tenocytes are the terminally differentiated cells resident to tendon and are generally responsible for maintaining ECM homeostasis. Tenocytes align along the proximal-distal axis parallel to fiber direction, extending projections deep into their extracellular environment and maintaining cell-cell connectivity through cadherin-11 junctions [16]. Matrix metalloproteinases (MMPs) degrade ECM and include secreted gelatinases (MMP-2 and MMP-9), collagenases (MMP-1, MMP-8, and MMP-13), and stromelysins 
(MMP-3, MMP-10, and MMP-11) among others [17, 18]. Dysregulation of these enzymes is a trait of degeneration: MMP2, MMP-3, MMP-14, and MMP-19 are significantly upregulated in human tendinopathy [19]. Healthy tenocytes deposit collagen to counteract this degradation [20]. The metabolic activities of tendon cells differ from tendon to tendon, and it is uncertain if this is a developmental trait or the result of adaptation to a specific mechanical environment [21].

Glycosaminoglycans (GAGs) are linear polysaccharide chains covalently bonded to proteoglycan cores within the ECM [3]. GAGs are important extracellular regulators, assisting in the lateral aggregation of type-I collagen [22] and water homeostasis [23], altering tissue biomechanics, and resisting compression [24, 25]. GAGs also nonspecifically bind growth factors, giving the ECM additional regulatory properties [26]. GAG content must be carefully maintained, as over- or underproduction has negative effects. In addition to remodeling collagen, tenocytes are responsible for managing proteoglycan turnover. In bovine deep flexor tendon explants, large proteoglycans have half-lives of approximately two days [27]. This is comparatively rapid for ECM proteins, particularly as carbon turnover virtually ceases in humans after adolescence [28]. Changes in proteoglycan turnover likely come before detectable structural alterations [29]. Increased GAG content has been found in diseased tendons [30], while GAG digestion lowers viscoelasticity [31, 32]. GAG exposure in damaged tendon may also be an irritant related to the pain of tendinopathy [33]. Thus GAGs are inexorably tied to tendon health.

The mechanical behavior of tendon and other materials is frequently represented in a stress/strain curve, which plots elongation versus force per cross-sectional area [34]. The classical response demonstrates an initial toe region, a linearelastic region, a plastic deformation region, and a point of failure. This model fits the deformation properties of ligament and tendon, and parameters of this relationship change during injury and aging $[35,36]$, ultimately altering cellular behavior [37]. As a complex viscoelastic biomaterial, tendons also exhibit force-relaxation, creep, and hysteresis [38]. While several natural and synthetic scaffolds are available as alternatives, the easiest way to replicate the totality of the properties of native tendon is to use decellularized tendon as a substrate. The scientific and clinical value of decellularized tendon scaffolds (DTS) may be further enhanced using cultivation tools such as bioreactors.

In the context of tissue engineering, the term "bioreactor" describes any (typically in vitro) culture system that not only sustains the life of cells/tissues outside the body but also enriches the cellular environment with dynamic stimuli designed to promote a particular phenotype. Soft tissue bioreactors are still in their infancy, with few biomimetic scaffold systems available. Even rarer are systems incorporating naturally derived scaffolds, despite the long history of tendon allografts in clinical practice. DTS remains the only option possessing the (1) structure, (2) composition, and (3) biomechanical properties of native tendon. This review will outline historical and current developments in the area of decellularized tendon scaffolds and their application in bioreactor systems.

\section{Tendon Decellularization}

Tendon autotransplantation developed as a discipline in response to unprecedented numbers of combat casualties in the wake of World War I [39], but it was not until the mid1950s that allografts [40] and artificial tendons [41] first entered trials. Tendon healing after trauma is ordinarily accomplished by a combination of cells both intrinsic and extrinsic to the tendon mid-substance [42], but it was uncertain how tendon grafts integrated with the host, and in turn how that process might be improved. Tendon scaffold was first used for the purpose of basic cell biological research in 1986, when rabbit quadriceps patellar tendon autografts were flash-frozen in liquid nitrogen and used for anterior cruciate ligament (ACL) reconstruction in order to demonstrate the donor origin of repopulating cells [43]. While not "decellularized," these constructs were devoid of live donor cells, allowing the first observations into the active role of cells in tendon homeostasis. Infiltration by peripheral cells was found to be insufficient to restore full biomechanical functionality. The failure strain of freeze-killed medial collateral ligaments (MCLs) orthotopically transplanted in a rabbit model decreased by $25 \%$ versus their fresh cell-containing counterparts nearly one year after the operation [44]. Cells quickly became the focus of tendon reconstructive research after this discovery [45]. Achilles tendon prostheses containing autologous MSCs dramatically enhanced gap defect healing in rabbits [46]. Since that time, a tissue engineering approach combining cells and scaffolds has been widely explored in effort to enhance tendon regeneration [47].

Decellularization protocols were invented in order to prevent the immunogenicity seen following anterior cruciate ligament repairs with freeze-dried allograft of xenograft [48]. Though some aspects of collagen structure are not conserved, the primary agents responsible for inciting tendon graft rejection are donor cells [49]. Decellularization is necessary to promote an M2 decision in the "fight or fix [50]" host macrophage response [51]. The predominance of type-I collagen in tendon ECM poses a particularly low immunological risk once cells are removed [52]. Chloroform-methanol extraction was the first chemical decellularization technique to achieve widespread use $[53,54]$. Since that time, techniques for cell removal have been incrementally improved, with increasing emphasis on tissue engineering.

Modern decellularization protocols most commonly apply detergents to solubilize cell debris. Detergents can disrupt collagen banding and mechanical properties [55], so a balance must be found in removing cells but preserving ECM. A limited number of systematic detergent decellularization protocols exist in the literature, and all use surfactants such as sodium dodecyl sulfate (SDS) and 4-octylphenol polyethoxylate (Triton X-100) or the organophosphorus solvent tri( $n$-butyl)phosphate (TnBP). Cartmell and Dunn compared the effects of Triton X-100, TnBP, and SDS at 0.5$2.0 \%$ concentration on rat tail tendons for 12-48 hours and found that $1 \%$ SDS for 24 hours or $1 \%$ TnBP for 48 hours most effectively removed cells and maintained histological 
and biomechanical features of normal tendon [56]. Woods and Gratzer observed that, of two-step detergent protocols involving 48 -hour incubation in $1 \%$ Triton X-100 followed by another 48 hours in $1 \%$ solutions of SDS, Triton X-100, or TnBP, the Triton-SDS combination worked best for $300 \mu \mathrm{m}$ thick canine Achilles tendon ribbons [57]. Interestingly, the same group discovered that a different combination (TritonTnBP) was more effective at porcine ACL decellularization [58]. Xing and colleagues compared 24-hour incubations of $1 \%$ Triton X-100, $0.5 \%$ SDS, $1 \%$ TnBP, $1 \%$ Triton X-100 with $0.5 \%$ SDS, $1 \%$ TnBP with $0.5 \%$ SDS, and $1 \%$ TnBP with $1 \%$ SDS to decellularize rabbit semitendinosus and flexor digitorum tendons and found $1 \%$ Triton X-100 with $0.5 \%$ SDS to be most effective in removing cells without damaging mechanical strength [59]. Deeken et al. compared 1\% Triton X-100 and $1 \%$ Triton X-100 with $1 \%$ TnBP, $2 \%$ TnBP, $1 \%$ TnBP, $1 \%$ SDS, and $2 \%$ SDS and found $1 \%$ TnBP to be most effective at decellularizing porcine diaphragm tendon [60].

Our group was the first to use an equine tendon scaffold for tissue engineering applications. This model is advantageous due to the size, availability, low vascularity, and high mechanical strength of equine tendons relative to other species. Briefly, we compared the effect of $1 \% \mathrm{TnBP}$, $1 \%$ SDS, $2 \%$ SDS, and $0.5 \%$ Triton X-100 with $0.5 \%$ SDS with a detergent-free group on $400 \mu \mathrm{m}$ thick equine flexor digitorum superficialis tendon (FDST) ribbons, finding that $2 \%$ SDS in combination with other methods provided a nearly cell-free, biomechanically robust, and biocompatible scaffold material $[61,62]$. Flexor tendon allografts needed for hand reconstruction typically fall within the range of 2-7 cm [63], and decellularized equine FDST ribbons may prove to be ideally suited for this application. Burk et al. later decellularized full-thickness equine FDST samples using 48 hours of $1 \%$ Triton X-100 incubation in combination with freeze/thaw cycles [64]. On the human side, Pridgen et al. compared $1 \%$ Triton X-100, $1 \%$ TnBP, $1 \%$ SDS, and $0.1 \%$ SDS, and $0.1 \%$ SDS was sufficient to decellularize FDST and flexor digitorum profundus tendon (FDPT) [65]. Hammer et al. decellularized human iliotibial tract using $1 \%$ SDS, noting incomplete DNA removal (44.7\% residual) and native tensile properties, and incorrectly stating that theirs was the first study to compare matched native and decellularized tendon samples [66]. Other techniques such as freeze/thaw cycles [67], hypotonic solutions [68], nucleases [69], oxidizing agents [70], and irradiation [71] have also been used on tendon, alone or in combinations with detergents.

Human FDPTs, decellularized in SDS and implanted into outbred rats, had decreased immunogenicity and improved mechanical properties versus nondecellularized counterparts [72]. A similar result was seen in 2\% SDS-decellularized rat Achilles tendons [73]. Of the commercial tissue augmentation materials surgically used for tendon reconstruction, those that are based on natural collagen matrices are stronger and better retain sutures [74, 75]. However, the most common products, such as Graftjacket RTM (Kinetic Concepts, Inc.), Allopatch HD (Musculoskeletal Transplant Foundation), and TissueMend Soft Tissue Repair Matrix (Stryker), are (human and human and bovine, resp.) dermal allografts and lack the standalone biomechanical properties of tendon. Full coverage of nontendinous ECM scaffolds is beyond the scope of this review, but some groups have experimented with surface modification or reinforcement techniques to add mechanical strength to ECM sheets [76-78], while others embrace the sacrificial nature of weak but rapidly remodeled scaffolds as encouraging de novo tissue growth. As previously stated, tendon grafts lacking live cells are in widespread use for ACL replacement but do not fully restore native function [79]. It can take three years or longer for allografts to reach peak integration, which nevertheless remains incomplete and weak compared to healthy tissue [80]. While some groups are experimenting with functionalization or composite techniques [81], another potential solution to this problem is to provide a cell population that remodels and strengthens the scaffold over time.

Reseeded decellularized tendon scaffolds have demonstrated strong potential as graft materials [82], but animal testing is required [83]. Multilayer composites of decellularized canine infraspinatus tendons laden with rabbit bone marrow-derived MSCs remained vital, began to express tenomodulin, and altered collagen and matrix metalloproteinase activity [84]. Rabbit rotator cuffs repaired with matrix performed better after 8 weeks when seeded with tendon cells [85]. Human FDPT decellularized in 0.1\% SDS and peracetic acid then seeded with adipose-derived MSCs implanted subcutaneously in nude mice remained healthy and viable for one month [86]. Reseeded Triton X-100-treated rat Achilles tendons were stronger and better organized after 24 hours in a surgical replacement model [87]. However, cellladen tendon constructs cultured ex vivo without mechanical manipulation actively degrade their scaffolds, necessitating culture techniques that fulfill the need for cells to experience stimulation [88].

\section{Tendon Bioreactors}

In vitro cell culture was pioneered by Carrel at the turn of the 20th century. By nourishing tissue explants in plasma enriched with various animal-derived extracts, Carrel extended the life expectancy and proliferative capacity of cells in culture from weeks to months $[89,90]$. Realizing that diffusion-limited nutrient flow hindered not only the size of tissue explants but also the vitality of transplant organs, Carrel, in collaboration with Lingbergh, coinvented "an apparatus for the culture of whole organs" [91], the first perfusion bioreactor.

Musculoskeletal loading plays an important role in tissue homeostasis, a fact that gained increasing attention as humans established technologies facilitating spaceflight. Astronauts experience reversible bone demineralization [92], which is attributed to attenuated bone formation but retained bone resorption while in orbit [93]. It was recognized that rat bone marrow cells lose osteogenic potential when unloaded in vivo [94] but have improved osteogenic potential when cultured on flexible-bottom culture dishes subject to $1 \mathrm{~Hz}$ deformation cycles [95]. As gravitational and locomotive forces have been essential evolutionary conditions, many tissues experience similar phenomena. ECM forces and cell shape result in fate decisions including differentiation and 
apoptosis [96], and transplanting cells can induce progenitor cell differentiation into tissues other than their source of origin [97]. Modern musculoskeletal bioreactors are direct decedents of these discoveries and attempt to manipulate these effects. Deformation protocols are most efficacious when they resemble the in vivo environment [98], as cells respond differently to deformations induced by compression versus tension [99].

Elastic deformation of tendon occurs at the $100 \mu \mathrm{m}$ level by straightening of fibrillar crimp and then at the 10$15 \mathrm{~nm}$ level by molecular elongation of collagen helices [100]. Sensation of these cell-scale forces, such as through integrinactivated MAP kinase and NF- $\kappa \mathrm{B}$ signaling or by stressresponsive gene enhancers, is essential to proper tenocyte phenotype [101]. Stretch also alters the availability and rate of ECM binding domains involved in assembly and degradation [102]. Tendons deprived of mechanical stimulation in vitro experience profound negative alterations including changes in anatomical size, a near complete loss of biomechanical function, hypercellularity, and decreased ECM alignment [103]. This occurs even in tendons frozen in situ [104]: a treatment which may in fact exacerbate ECM catabolism through proteolytic enzyme release. Cells exhibit sensitivity to subtle changes in their mechanical environment, with small deformations frequently leading to an anabolic and anti-inflammatory response and large deformations leading to inflammation and ECM damage [105]. Selectivity to static versus dynamic forces of the same magnitude is also provided by differences in resistance to conformational change among components of intracellular focal adhesion complexes [106]. While other types of bioreactors such as microcarriers [107, 108], flow perfusion, and shear systems [109-112] and hydrostatic bioreactors [113] exist, this review focuses on systems involving stretching or mechanical load that attempt to model natural deformation.

Banes made pioneering advances in the musculoskeletal mechanobiology field with his invention of the Flexcell bioreactor platform in 1985 [114]. This system uses flexiblebottom circular culture wells deformed via vacuum to deliver controlled mechanical signals to cells, allowing mechanistic in vitro studies of tendon and ligament signaling [115]. For example, ligaments undergo atrophy when unloaded, as sensed via fibronectin-specific integrin $\alpha_{5} \beta_{1}$ and other mechanisms [116]. Cell stretching not only encourages tissue anabolism but also results in cell-mediated ECM recomposition. Primary human MCL cells increasingly express type-III collagen under $7.5 \%$ but not $5 \%$ strain in a Flexcell bioreactor at $1 \mathrm{~Hz}$ for $16-25$ hours [117]. This effect is not observed in cells derived from synovium [118]. Human tendon fibroblasts secrete the growth factors TGF- $\beta$, bFGF, and PDGF in response to stretch on the timescale of hours [119]. Flexcell bioreactors can be programmed to conform to virtually any waveform desired, but the resulting deformation is only precise in the center of each well [120], even after careful calibration [121]. A slightly more uniform approach is to use a uniaxial stretch system to deform rectangular silicon dishes using a stepper motor, the use of which demonstrated TGF$\beta 1$-mediated expression of type-I and type-III collagen in human ACL fibroblasts [122].
Scaffold-free flexible plastic may be considered the first generation of tendon/ligament bioreactors. While they represent a tremendous increase in complexity versus traditional monolayer culture, they are far from modeling the in vivo environment. Second-generation bioreactors are based on three-dimensional scaffolds but do not mimic the alignment or function of native tendon. As the principle component of tendons and ligaments, type-I collagen is the most common base, but the lack of hierarchical organization in collagen hydrogels makes them structurally inferior for translational use [123]. Tendon cells do, however, interact with collagen gels, resulting in changes in phenotype [124]. Butler's group has developed functionalized type-I collagen-based sponge constructs for tendon repair that can withstand forces experienced in rabbits [125-127]. Rabbit bone marrow-derived MSCs embedded in these sponges established maximum stiffness when cultured at $2.4 \%$ strain at $1 \mathrm{~Hz}$ for 50 minutes per day [128]. Human tenocytes cultured in reconstituted rat tail collagen stretched at $5 \%$ strain at $1 \mathrm{~Hz}$ for 48 hours resulted in differential expression of several proteases and matrix proteins, as well as TGF $\beta$ activation [129]. Many natural but isotropic materials used for surgical augmentation have been used in bioreactors with varying results, including porcine small intestine submucosa [130] and human umbilical veins [131], as well as designer scaffolds such as the woven hyaluronic acid-based Hyalonect [132]. Biaxial deformation is possible in these bioreactors [133], but multiaxial strain is not typically applicable to tendon physiology.

Synthetic hydrogels are also commonly implemented, and their properties are tunable [134]. A commercial human MSC line encapsulated in poly(ethylene glycol)- (PEG-) based scaffolds under $10 \%$ strain at $1 \mathrm{~Hz}$ for alternative 3 hour on/off periods for 21 days resulted in upregulation of tenocytic genes including collagens and tenascin- $C$ [135]. Rabbit Achilles tendon cells in porous poly(L-lactide-co- $\varepsilon$ caprolactone) (PLCL) scaffolds under $10 \%$ strain at $0.25 \mathrm{~Hz}$ for 400 minutes per day for 4 weeks demonstrated enhanced proliferation and type-I collagen deposition [136]. 3D culture is critical for proper morphology, but disordered hydrogels do not deform via the same mechanisms of native ECM. Hydrogels contract and remodel and may begin to establish alignment but do not resemble tendon $[137,138]$. Cultured MSC sheets deposit ECM on plastic, which can also be used as a simple matrix. One study using such a system discovered that both mechanical forces and scleraxis can independently induce tenogenesis, but their influences are synergistic and most effective when combined [139]. This strategy falls into the same technical class as hydrogels: useful but not biomimetic. Nevertheless, fundamental signaling information, such as the nature of the refractory period following periods of mechanical stimulation [140], is likely conserved. However, heterogeneity in the structural properties of different systems complicates comparisons, such as cell-scale felt strain.

Third-generation bioreactors implement aligned scaffolds, natural or synthetic, and more faithfully recapitulate tendon structure and alignment but are not biomechanically functional as standalone replacement tendons. Rat MCL cells 
aligned on collagen-coated polydimethylsiloxane (PDMS) scaffolds demonstrated increased cell-cell calcium signaling sensitivity versus nonaligned controls [141]. Another option is to use synthetic nano/microfibers. These have better structural similarity to tendon, induce spindle morphology, and when sized correctly provide structural cues that aid in tenogenesis [142]. Human ligament fibroblasts cultured on electrospun polyurethane nanofibers increased ECM production in response to $5 \%$ strain at $0.2 \mathrm{~Hz}$ in a modified Flexcell bioreactor [143]. Cardwell et al. cultured C3H10T1/2 MSCs on electrospun poly(ester urethane) urea fibers, loaded daily by $4 \%$ strain at $0.5 \mathrm{~Hz}$ for 30 minutes, witnessing alignment and a tenocytic gene expression profile [144]. Silk scaffolds are widely used by Moreau and his collaborators as a platform for MSC differentiation toward ligament [145]. Aligned, crosslinked collagen fibers most closely approximate the structural and mechanical properties of native tendon. In a recent study by Qiu et al., human bone marrow-derived MSCs cultured under $10 \%$ strain at $1 \mathrm{~Hz}$ for alternating 3-hour on/off cycles for 14 days proliferated more and expressed greater amounts of scleraxis, tenascin- $C$, and collagens than their static counterparts [146].

The most holistic tendon bioreactors use decellularized tendon matrix as a scaffold subject to cyclic strain. These are the fourth-generation tendon bioreactors, which replicate not only the mechanical environment of native tendon but also the complex ultrastructure, composition, and biomechanical properties. There are currently only four principle investigators using this technique: Chang of Stanford University, Van Dyke of Wake Forest University, Barrett at Virginia Tech, and Zhao at Mayo Clinic. Chang's group released back-toback "Tissue Engineering: Part A" papers in 2010, characterizing the response of rabbit and human flexor tendon constructs cultured in Ligagen L30-series axial bioreactors. P1 rabbit FDPT-derived cells cultured on decellularized FDPT increased construct elastic modulus and ultimate tensile strength in response to cyclic $1.25 \mathrm{~N}$ strains at $0.0167 \mathrm{~Hz}$ for alternating one-hour periods over 5 days [147]. In a similar study with matched human FDST and EDST sets (P4) with $0.625 \mathrm{~N}-2.5 \mathrm{~N}$ strains over $3-8$ days, the investigators observed time-dependent improvements in biomechanical properties but no differences between groups of different load magnitudes [148]. Constructs then degraded after two days of disuse. Van Dyke's group released a 2013 paper using allogeneic chicken FDPT constructs (P4) exposed to 5\% strain at $1 \mathrm{~Hz}$ for one hour per day for 7 days in the same Ligagen system. Cells preserved construct mechanical properties versus unseeded controls, but no significant changes in mRNA profiles were seen resulting from strain [149]. Our group used a custom bioreactor to characterize amplitudedependent gene expression profiles of $\mathrm{P} 2$ horse bone marrow MSCs, finding that $3 \%$ strain at $0.33 \mathrm{~Hz}$ for one hour per day increased ultimate tensile strength and induced high expression of scleraxis, type-I collagen, and proteoglycans [62]. Qin et al. released the results of a similar study after our 2015 Journal of Orthopaedic Research article was published, reaching analogous conclusions in a canine Achilles tendon model [150].

\section{Applications}

Bioreactors are used for (1) basic pathway studies, (2) growing replacement tissues, (3) maintenance of organ vitality ex vivo, and (4) priming therapeutic cells prior to cell transplantation. The first tendon tissue bioreactor study was conducted by Arnoczky's group, when Hannafin et al. found that canine FDPT maintained its mechanical properties ex vivo for 4 weeks while unloaded controls degraded [151]. Lavagnino et al. later performed multiple sets of experiments to determine that frequency and amplitude resulted in dose-dependent increases in MMP-1 expression in rat tail tendons [152]. This technique is still being used to elucidate pathways involved in tendon adaptation to exercise, such as collagen and IL-6 expression [153], as well as damage resulting from repetitive loading [154] and cellular maintenance of biomechanical properties [155].

Living animals also provide valuable information for in vitro bioreactors. For example, following a single loading episode in rat Achilles tendons, gene expression returns to baseline after one day [156], but as little as 5 minutes of loading over 4 days is enough to improve mechanical properties [157]. While the use of animals cannot be eliminated, bioreactors reduce the necessity of laboratory animal experiments consistent with the 3Rs [158], namely, by reducing the numbers needed (by harvesting tissues at necropsy from unrelated studies for bioreactor use) and replacing them with comparable methods (synthetic scaffolds). In addition to tendon/ligament, cyclic-strain bioreactors are excellent platforms for cultivating muscle material, such as for the repair of critical-size volumetric defects $[159,160]$ or even artificial meat [161].

The practice of cell therapy in human and animal medicine has witnessed a recent surge in popularity and commercial viability [162]. Bioreactors will assist in gathering necessary efficacy data for these procedures. Furthermore, the decision of cell source, which influences differentiation capacity [163], is one such application of these systems. Indeed, one aim of our current work is to use our bioreactor to provide standardized in vitro comparisons on different commonly used stem cell sources for tendon cell therapy.

Uncertainty concerning the long-term vitality of transplanted cells and their relationship to the host is a challenge and opportunity for future development within the field. As graft size increases, so does its need for a relationship with the surrounding vasculature. Perhaps, depending on the state of niche factors in tendon and the surrounding environment, neovascularization and/or infiltration of host cells extrinsic to the graft may result in deterioration rather than strengthening of the tissue [164]. Designing grafts that avoid inflammatory damage [165] and promote a healthy graft-host relationship is essential. The identities of cells participating in tendon regeneration and the molecular pathways coordinating this behavior remain undefined [166]. Moving forward, improved in vitro models will likely help answer these unanswered questions. 


\section{Summary}

Tendons are dynamic tissues, and tendon pathologies significantly reduce quality of life. There are no effective pharmacological therapies currently available to treat tendinopathies, and should tissue replacement be necessary, donor-matched prostheses are frequently unavailable. Recent developments in ex vivo modeling techniques have allowed us to dissect structure/function relationships and elucidate cell-ECM interactions with unprecedented accuracy and environmental control. Bioreactors are the best available tools for developing novel regenerative treatments and cultivating functional replacement tissue. Future iterations of bioreactor technology may be even better suited to these aims and will likely be capable of replicating multitissue or transitional structures by becoming increasingly complex.

\section{Conflict of Interests}

One of the authors (Jennifer G. Barrett) is on the Scientific Advisory Board of ReCellerate, Inc. Otherwise, no potential conflict of interests exists.

\section{References}

[1] A. E. Minetti, L. P. Ardigò, E. Reinach, and F. Saibene, "The relationship between mechanical work and energy expenditure of locomotion in horses," Journal of Experimental Biology, vol. 202, no. 17, pp. 2329-2338, 1999.

[2] D. L. Christiansen, E. K. Huang, and F. H. Silver, "Assembly of type I collagen: fusion of fibril subunits and the influence of fibril diameter on mechanical properties," Matrix Biology, vol. 19, no. 5, pp. 409-420, 2000.

[3] P. Kannus, "Structure of the tendon connective tissue," Scandinavian Journal of Medicine and Science in Sports, vol. 10, no. 6, pp. 312-320, 2000.

[4] M. O’Brien, "Structure and metabolism of tendons," Scandinavian Journal of Medicine and Science in Sports, vol. 7, no. 2, pp. 55-61, 1997.

[5] V. Léjard, G. Brideau, F. Blais et al., "Scleraxis and NFATc regulate the expression of the pro- $\alpha 1$ (I) collagen gene in tendon fibroblasts," Journal of Biological Chemistry, vol. 282, no. 24, pp. 17665-17675, 2007.

[6] L. Espira, L. Lamoureux, S. C. Jones, R. D. Gerard, I. M. C. Dixon, and M. P. Czubryt, "The basic helix-loop-helix transcription factor scleraxis regulates fibroblast collagen synthesis," Journal of Molecular and Cellular Cardiology, vol. 47, no. 2, pp. 188-195, 2009.

[7] S. R. Lamande and J. F. Bateman, "Procollagen folding and assembly: the role of endoplasmic reticulum enzymes and molecular chaperones," Seminars in Cell and Developmental Biology, vol. 10, no. 5, pp. 455-464, 1999.

[8] Y. Ezura, S. Chakravarti, A. Oldberg, I. Chervoneva, and D. E. Birk, "Differential expression of lumican and fibromodulin regulate collagen fibrillogenesis in developing mouse tendons," Journal of Cell Biology, vol. 151, no. 4, pp. 779-787, 2000.

[9] C. M. Lapiere, B. Nusgens, and G. E. Pierard, "Interaction between collagen type I and type III in conditioning bundles organization," Connective Tissue Research, vol. 5, no. 1, pp. 2129, 1977.
[10] N. Maffulli, S. W. B. Ewen, S. W. Waterston, J. Reaper, and V. Barrass, "Tenocytes from ruptured and tendinopathic Achilles tendons produce greater quantities of type III collagen than tenocytes from normal Achilles tendons an in vitro model of human tendon healing," The American Journal of Sports Medicine, vol. 28, no. 4, pp. 499-505, 2000.

[11] D. E. Birk, J. M. Fitch, J. P. Babiarz, K. J. Doane, and T. F. Linsenmayer, "Collagen fibrillogenesis in vitro: interaction of types I and V collagen regulates fibril diameter," Journal of Cell Science, vol. 95, no. 4, part 4, pp. 649-657, 1990.

[12] A. Neuberger, J. C. Perrone, and H. G. Slack, "The relative metabolic inertia of tendon collagen in the rat," The Biochemical Journal, vol. 49, no. 2, pp. 199-204, 1951.

[13] J.-H. Chen, C. Liu, L. You, and C. A. Simmons, "Boning up on Wolff's Law: mechanical regulation of the cells that make and maintain bone," Journal of Biomechanics, vol. 43, no. 1, pp. 108118, 2010.

[14] P. Malaviya, D. L. Bultler, G. P. Boivin et al., "An in vivo model for load-modulated remodeling in the rabbit flexor tendon," Journal of Orthopaedic Research, vol. 18, no. 1, pp. 116-125, 2000.

[15] E. L. Batson, R. J. Paramour, T. J. Smith, H. L. Birch, J. C. Patterson-Kane, and A. E. Goodship, "Are the material properties and matrix composition of equine flexor and extensor tendons determined by their functions?" Equine Veterinary Journal, vol. 35, no. 3, pp. 314-318, 2003.

[16] S. H. Richardson, T. Starborg, Y. Lu, S. M. Humphries, R. S. Meadows, and K. E. Kadler, "Tendon development requires regulation of cell condensation and cell shape via cadherin-11mediated cell-cell junctions," Molecular and Cellular Biology, vol. 27, no. 17, pp. 6218-6228, 2007.

[17] H. Birkedal-Hansen, W. G. Moore, M. K. Bodden et al., "Matrix metalloproteinases: a review," Critical Reviews in Oral Biology \& Medicine, vol. 4, no. 2, pp. 197-250, 1993.

[18] Y. Hosaka, S. Ozoe, R. Kirisawa, H. Ueda, K. Takehana, and M. Yamaguchi, "Effect of heat on synthesis of gelatinases and proinflammatory cytokines in equine tendinocytes," Biomedical Research, vol. 27, no. 5, pp. 233-241, 2006.

[19] T. A. H. Järvinen, P. Kannus, N. Maffulli, and K. M. Khan, "Achilles tendon disorders: etiology and epidemiology" Foot and Ankle Clinics, vol. 10, no. 2, pp. 255-266, 2005.

[20] G. P. Riley, V. Curry, J. DeGroot et al., "Matrix metalloproteinase activities and their relationship with collagen remodelling in tendon pathology," Matrix Biology, vol. 21, no. 2, pp. 185-195, 2002.

[21] H. L. Birch, "Tendon matrix composition and turnover in relation to functional requirements," International Journal of Experimental Pathology, vol. 88, no. 4, pp. 241-248, 2007.

[22] Y. Lanir, "A microstructure model for the rheology of mammalian tendon," Journal of Biomechanical Engineering, vol. 102, no. 4, pp. 332-339, 1980.

[23] J. E. Scott, "Extracellular matrix, supramolecular organisation and shape," Journal of Anatomy, vol. 187, no. 2, pp. 259-269, 1995.

[24] H. R. C. Screen, "Investigating load relaxation mechanics in tendon," Journal of the Mechanical Behavior of Biomedical Materials, vol. 1, no. 1, pp. 51-58, 2008.

[25] E. L. Abreu, D. Leigh, and K. A. Derwin, "Effect of altered mechanical load conditions on the structure and function of cultured tendon fascicles," Journal of Orthopaedic Research, vol. 26, no. 3, pp. 364-373, 2008.

[26] J. Taipale and J. Keski-Oja, "Growth factors in the extracellular matrix," The FASEB Journal, vol. 11, no. 1, pp. 51-59, 1997. 
[27] T. Samiric, M. Z. Ilic, and C. J. Handley, "Large aggregating and small leucine-rich proteoglycans are degraded by different pathways and at different rates in tendon," European Journal of Biochemistry, vol. 271, no. 17, pp. 3612-3620, 2004.

[28] K. M. Heinemeier, P. Schjerling, J. Heinemeier, S. P. Magnusson, and M. Kjaer, "Lack of tissue renewal in human adult Achilles tendon is revealed by nuclear bomb 14C," The FASEB Journal, vol. 27, no. 5, pp. 2074-2079, 2013.

[29] J. Parkinson, T. Samiric, M. Z. Ilic, J. Cook, and C. J. Handley, "Involvement of proteoglycans in tendinopathy," Journal of Musculoskeletal Neuronal Interactions, vol. 11, no. 2, pp. 86-93, 2011.

[30] S. Tom, J. Parkinson, M. Z. Ilic, J. Cook, J. A. Feller, and C. J. Handley, "Changes in the composition of the extracellular matrix in patellar tendinopathy," Matrix Biology, vol. 28, no. 4, pp. 230-236, 2009.

[31] H. R. C. Screen, "Hierarchical approaches to understanding tendon mechanics," Journal of Biomechanical Science and Engineering, vol. 4, no. 4, pp. 481-499, 2009.

[32] G. Fessel and J. G. Snedeker, "Equivalent stiffness after glycosaminoglycan depletion in tendon-an ultra-structural finite element model and corresponding experiments," Journal of Theoretical Biology, vol. 268, no. 1, pp. 77-83, 2011.

[33] K. M. Khan, J. L. Cook, N. Maffulli, and P. Kannus, "Where is the pain coming from in tendinopathy? It may be biochemical, not only structural, in origin," British Journal of Sports Medicine, vol. 34, no. 2, pp. 81-83, 2000.

[34] D. C. Taylor, J. D. Dalton Jr., A. V. Seaber, and W. E. Garrett Jr., "Viscoelastic properties of muscle-tendon units-the biomechanical effects of stretching," The American Journal of Sports Medicine, vol. 18, no. 3, pp. 300-309, 1990.

[35] S. L.-Y. Woo, M. A. Gomez, and W. H. Akeson, "The time and history-dependent viscoelastic properties of the canine medial collateral ligament," Journal of Biomechanical Engineering, vol. 103, no. 4, pp. 293-298, 1981.

[36] G. A. Johnson, D. M. Tramaglini, R. E. Levine, K. Ohno, N.-Y. Choi, and S. L.-Y. Woo, "Tensile and viscoelastic properties of human patellar tendon," Journal of Orthopaedic Research, vol. 12, no. 6, pp. 796-803, 1994.

[37] D. E. Discher, P. Janmey, and Y.-L. Wang, "Tissue cells feel and respond to the stiffness of their substrate," Science, vol. 310, no. 5751, pp. 1139-1143, 2005.

[38] C. N. Maganaris, M. V. Narici, L. C. Almekinders, and N. Maffulli, "Biomechanics and pathophysiology of overuse tendon injuries: ideas on insertional tendinopathy," Sports Medicine, vol. 34, no. 14, pp. 1005-1017, 2004.

[39] W. G. Turner, "Recent advances in tendon transplantation and bone grafting," Canadian Medical Association Journal, vol. 10, no. 8, pp. 705-709, 1920.

[40] W. C. Graham, D. A. Smith, and M. P. McGuire, "The use of frozen stored tendons for grafting: an experimental study," The Journal of Bone \& Joint Surgery-American Volume, vol. 37, p. 624, 1955.

[41] T. Takahashi, "Experimental studies on core materials for artificial tendons and ligaments, especially on the superiority of Amilan (Nylon) cores," Journal of Orthopaedic Science, vol. 29, pp. 535-558, 1955.

[42] G. Lundborg, H. A. Hansson, F. Rank, and B. Rydevik, "Superficial repair of severed flexor tendons in synovial environment: an experimental, ultrastructural study on cellular mechanisms," Journal of Hand Surgery, vol. 5, no. 5, pp. 451-461, 1980.
[43] J. B. Kleiner, D. Amiel, R. D. Roux, and W. H. Akeson, "Origin of replacement cells for the anterior cruciate ligament autograft," Journal of Orthopaedic Research, vol. 4, no. 4, pp. 466-474, 1986.

[44] G. J. W. King, P. Edwards, R. F. Brant, N. G. Shrive, and C. B. Frank, "Freezing influences the healing of rabbit medial collateral ligament autografts," Clinical Orthopaedics and Related Research, no. 316, pp. 244-253, 1995.

[45] Y. Cao, J. P. Vacanti, X. Ma et al., "Generation of neo-tendon using synthetic polymers seeded with tenocytes," Transplantation Proceedings, vol. 26, no. 6, pp. 3390-3392, 1994.

[46] R. G. Young, D. L. Butler, W. Weber, A. I. Caplan, S. L. Gordon, and D. J. Fink, "Use of mesenchymal stem cells in a collagen matrix for achilles tendon repair," Journal of Orthopaedic Research, vol. 16, no. 4, pp. 406-413, 1998.

[47] A. I. Caplan, "Adult mesenchymal stem cells for tissue engineering versus regenerative medicine," Journal of Cellular Physiology, vol. 213, no. 2, pp. 341-347, 2007.

[48] J. L. Pinkowski, P. R. Reiman, and S.-L. Chen, "Human lymphocyte reaction to freeze-dried allograft and xenograft ligamentous tissue," American Journal of Sports Medicine, vol. 17 , no. 5, pp. 595-600, 1989.

[49] A. Minami, S. Ishii, T. Ogino, T. Oikawa, and H. Kobayashi, "Effect of the immunological antigenicity of the allogeneic tendons on tendon grafting," Hand, vol. 14, no. 2, pp. 111-119, 1982.

[50] C. D. Mills, "M1 and M2 macrophages: oracles of health and disease," Critical Reviews in Immunology, vol. 32, no. 6, pp. 463488, 2012.

[51] T. J. Keane, R. Londono, N. J. Turner, and S. F. Badylak, "Consequences of ineffective decellularization of biologic scaffolds on the host response," Biomaterials, vol. 33, no. 6, pp. 1771-1781, 2012.

[52] A. K. Lynn, I. V. Yannas, and W. Bonfield, "Antigenicity and immunogenicity of collagen," Journal of Biomedical Materials Research B: Applied Biomaterials, vol. 71, no. 2, pp. 343-354, 2004.

[53] J. C. Tauro, J. R. Parsons, J. Ricci, and H. Alexander, "Comparison of bovine collagen xenografts to autografts in the rabbit," Clinical Orthopaedics and Related Research, no. 266, pp. 271284, 1991.

[54] M. C. Zimmerman, J. H. Contiliano, J. R. Parsons, A. Prewett, and J. Billotti, "The biomechanics and histopathology of chemically processed patellar tendon allografts for anterior cruciate ligament replacement," The American Journal of Sports Medicine, vol. 22, no. 3, pp. 378-386, 1994.

[55] X. W. Hu, D. P. Knight, and J. A. Chapman, "The effect of nonpolar liquids and non-ionic detergents on the ultrastructure and assembly of rat tail tendon collagen fibrils in vitro," Biochimica et Biophysica Acta-General Subjects, vol. 1334, no. 2-3, pp. 327337, 1997.

[56] J. S. Cartmell and M. G. Dunn, "Effect of chemical treatments on tendon cellularity and mechanical properties," Journal of Biomedical Materials Research, vol. 49, no. 1, pp. 134-140, 2000.

[57] T. Woods and P. F. Gratzer, "Effectiveness of three extraction techniques in the development of a decellularized bone-anterior cruciate ligament-bone graft," Biomaterials, vol. 26, no. 35, pp. 7339-7349, 2005.

[58] R. D. Harrison and P. F. Gratzer, "Effect of extraction protocols and epidermal growth factor on the cellular repopulation of decellularized anterior cruciate ligament allografts," Journal of Biomedical Materials Research A, vol. 75, no. 4, pp. 841-854, 2005. 
[59] S. Xing, C. Liu, B. Xu, J. Chen, D. Yin, and C. Zhang, "Effects of various decellularization methods on histological and biomechanical properties of rabbit tendons," Experimental and Therapeutic Medicine, vol. 8, no. 2, pp. 628-634, 2014.

[60] C. R. Deeken, A. K. White, S. L. Bachman et al., "Method of preparing a decellularized porcine tendon using tributyl phosphate," Journal of Biomedical Materials Research B Applied Biomaterials, vol. 96, no. 2, pp. 199-206, 2011.

[61] D. W. Youngstrom, J. G. Barrett, R. R. Jose, and D. L. Kaplan, "Functional characterization of detergent-decellularized equine tendon extracellular matrix for tissue engineering applications," PLoS ONE, vol. 8, no. 5, Article ID e64151, 2013.

[62] D. W. Youngstrom, I. Rajpar, D. L. Kaplan, and J. G. Barrett, “A bioreactor system for in vitro tendon differentiation and tendon tissue engineering," Journal of Orthopaedic Research, vol. 33, no. 6, pp. 911-918, 2015.

[63] J. Chai, H. Song, Z. Sheng, B. Chen, H. Yang, and L. Li, "Repair and reconstruction of massively damaged burn wounds," Burns, vol. 29, no. 7, pp. 726-732, 2003.

[64] J. Burk, I. Erbe, D. Berner et al., "Freeze-thaw cycles enhance decellularization of large tendons," Tissue Engineering C: Methods, vol. 20, no. 4, pp. 276-284, 2014.

[65] B. C. Pridgen, C. Y. L. Woon, M. Kim et al., "Flexor tendon tissue engineering: acellularization of human flexor tendons with preservation of biomechanical properties and biocompatibility," Tissue Engineering Part C: Methods, vol. 17, no. 8, pp. 819-828, 2011.

[66] N. Hammer, D. Huster, S. Fritsch et al., "Do cells contribute to tendon and ligament biomechanics?” PLoS ONE, vol. 9, no. 8, Article ID e105037, 2014.

[67] A. A. Stewart, J. G. Barrett, C. R. Byron et al., "Comparison of equine tendon-, muscle-, and bone marrow-derived cells cultured on tendon matrix," American Journal of Veterinary Research, vol. 70, no. 6, pp. 750-757, 2009.

[68] J. H. Ingram, S. Korossis, G. Howling, J. Fisher, and E. Ingham, "The use of ultrasonication to aid recellularization of acellular natural tissue scaffolds for use in anterior cruciate ligament reconstruction," Tissue Engineering, vol. 13, no. 7, pp. 1561-1572, 2007.

[69] L.-J. Ning, Y. Zhang, X.-H. Chen et al., "Preparation and characterization of decellularized tendon slices for tendon tissue engineering," Journal of Biomedical Materials Research A, vol. 100, no. 6, pp. 1448-1456, 2012.

[70] P. W. Whitlock, T. M. Seyler, G. D. Parks et al., "A novel process for optimizing musculoskeletal allograft tissue to improve safety, ultrastructural properties, and cell infiltration," The Journal of Bone \& Joint Surgery-American Volume, vol. 94, no. 16, pp. 1458-1467, 2012.

[71] K. Hwang, J. H. Hwang, J. H. Park, D. J. Kim, and Y. H. Shin, "Experimental study of autologous cartilage, acellular cadaveric dermis, lyophilized bovine pericardium, and irradiated bovine tendon: applicability to nasal tip plasty," Journal of Craniofacial Surgery, vol. 18, no. 3, pp. 551-558, 2007.

[72] S. S. Raghavan, C. Y. L. Woon, A. Kraus et al., "Human flexor tendon tissue engineering: decellularization of human flexor tendons reduces immunogenicity in vivo," Tissue Engineering Part A, vol. 18, no. 7-8, pp. 796-805, 2012.

[73] S. Farnebo, C. Y. L. Woon, J. A. Bronstein et al., "Decellularized tendon-bone composite grafts for extremity reconstruction: an experimental study," Plastic and Reconstructive Surgery, vol. 133, no. 1, pp. 79-89, 2014.
[74] F. A. Barber and J. Aziz-Jacobo, "Biomechanical testing of commercially available soft-tissue augmentation materials," Arthroscopy, vol. 25, no. 11, pp. 1233-1239, 2009.

[75] L. Song, R. E. Olsen, J. P. Spalazzi, and T. Davisson, "Biomechanical evaluation of acellular collagen matrix augmented Achilles tendon repair in sheep," Journal of Foot and Ankle Surgery, vol. 49, no. 5, pp. 438-441, 2010.

[76] C. Zhao, Y.-L. Sun, J. Ikeda et al., "Improvement of flexor tendon reconstruction with carbodiimide-derivatized hyaluronic acid and gelatin-modified intrasynovial allografts: study of a primary repair failure model," Journal of Bone and Joint Surgery $A$, vol. 92, no. 17, pp. 2817-2828, 2010.

[77] C. R. Deeken, M. J. Cozad, S. L. Bachman, B. J. Ramshaw, and S. A. Grant, "Characterization of bionanocomposite scaffolds comprised of amine-functionalized single-walled carbon nanotubes crosslinked to an acellular porcine tendon," Journal of Biomedical Materials Research Part A, vol. 96, no. 3, pp. 584594, 2011.

[78] C. R. Deeken, M. Esebua, S. L. Bachman, B. J. Ramshaw, and S. A. Grant, "Assessment of the biocompatibility of two novel, bionanocomposite scaffolds in a rodent model," Journal of Biomedical Materials Research Part B Applied Biomaterials, vol. 96, no. 2, pp. 351-359, 2011.

[79] U. Bosch, B. Decker, W. Kasperczyk, A. Nerlich, H.-J. Oestern, and $\mathrm{H}$. Tscherne, "The relationship of mechanical properties to morphology in patellar tendon autografts after posterior cruciate ligament replacement in sheep," Journal of Biomechanics, vol. 25, no. 8, pp. 821-830, 1992.

[80] T. I. Malinin, R. L. Levitt, C. Bashore, H. T. Temple, and W. Mnaymneh, "A study of retrieved allografts used to replace anterior cruciate ligaments," Arthroscopy, vol. 18, no. 2, pp. 163170, 2002.

[81] C. R. Deeken, D. B. Fox, S. L. Bachman, B. J. Ramshaw, and S. A. Grant, "Characterization of bionanocomposite scaffolds comprised of amine-functionalized gold nanoparticles and silicon carbide nanowires crosslinked to an acellular porcine tendon," Journal of Biomedical Materials Research Part B: Applied Biomaterials, vol. 97, no. 2, pp. 334-344, 2011.

[82] A. K. S. Chong, J. Riboh, R. L. Smith, D. P. Lindsey, H. M. Pham, and J. Chang, "Flexor tendon tissue engineering: acellularized and reseeded tendon constructs," Plastic and Reconstructive Surgery, vol. 123, no. 6, pp. 1759-1766, 2009.

[83] T. Tischer, S. Aryee, G. Wexel et al., "Tissue engineering of the anterior cruciate ligament-sodium dodecyl sulfate-acellularized and revitalized tendons are inferior to native tendons," Tissue Engineering Part A, vol. 16, no. 3, pp. 1031-1040, 2010.

[84] H. Omae, Y. L. Sun, K.-N. An, P. C. Amadio, and C. Zhao, "Engineered tendon with decellularized xenotendon slices and bone marrow stromal cells: an in vivo animal study," Journal of Tissue Engineering and Regenerative Medicine, vol. 6, no. 3, pp. 238-244, 2012.

[85] J. M. Chen, C. Willers, J. Xu, A. Wang, and M.-H. Zheng, "Autologous tenocyte therapy using porcine-derived bioscaffolds for massive rotator cuff defect in rabbits," Tissue Engineering, vol. 13, no. 7, pp. 1479-1491, 2007.

[86] T. Schmitt, P. M. Fox, C. Y. Woon et al., "Human flexor tendon tissue engineering: in vivo effects of stem cell reseeding," Plastic and Reconstructive Surgery, vol. 132, no. 4, pp. 567e-576e, 2013.

[87] C. Güngörmüş, D. Kolankaya, and E. Aydin, "Histopathological and biomechanical evaluation of tenocyte seeded allografts on rat Achilles tendon regeneration," Biomaterials, vol. 51, pp. 108118, 2015. 
[88] Y. Ikema, H. Tohyama, E. Yamamoto, F. Kanaya, and K. Yasuda, "Autologous tenocyte therapy using porcine-derived bioscaffolds for massive rotator cuff defect in rabbits," Clinical Biomechanics, vol. 22, no. 1, pp. 120-126, 2007.

[89] A. Carrel, "On the permanent life of tissues outside of the organism," The Journal of Experimental Medicine, vol. 15, no. 5, pp. 516-528, 1912.

[90] A. Carrel, "Artificial activation of the growth in vitro of connective tissue," Journal of Experimental Medicine, vol. 17, no. 1, pp. 14-19, 1913.

[91] C. A. Lindbergh, "An apparatus for the culture of whole organs," The Journal of Experimental Medicine, vol. 62, no. 3, pp. 409-431, 1935.

[92] P. C. Rambaut and R. S. Johnston, "Prolonged weightlessness and calcium loss in man," Acta Astronautica, vol. 6, no. 9, pp. 1113-1122, 1979.

[93] W. S. Jee, T. J. Wronski, E. R. Morey, and D. B. Kimmel, "Effects of spaceflight on trabecular bone in rats," The American Journal of Physiology, vol. 244, no. 3, pp. R310-R314, 1983.

[94] S. Keila, S. Pitaru, A. Grosskopf, and M. Weinreb, "Bone marrow from mechanically unloaded rat bones expresses reduced osteogenic capacity in vitro," Journal of Bone and Mineral Research, vol. 9, no. 3, pp. 321-327, 1994.

[95] G. P. Thomas and A. J. El Haj, "Bone marrow stromal cells are load responsive in vitro," Calcified Tissue International, vol. 58, no. 2, pp. 101-108, 1996.

[96] E. Ruoslahti, "Stretching is good for a cell," Science, vol. 276, no. 5317, pp. 1345-1346, 1997.

[97] D. Deng, W. Liu, F. Xu et al., "Engineering human neo-tendon tissue in vitro with human dermal fibroblasts under static mechanical strain," Biomaterials, vol. 30, no. 35, pp. 6724-6730, 2009.

[98] E. Yamamoto, D. Kogawa, S. Tokura, and K. Hayashi, "Effects of the frequency and duration of cyclic stress on the mechanical properties of cultured collagen fascicles from the rabbit patellar tendon," Journal of Biomechanical Engineering, vol. 127, no. 7, pp. 1168-1175, 2005.

[99] A. K. Haudenschild, A. H. Hsieh, S. Kapila, and J. C. Lotz, "Pressure and distortion regulate human mesenchymal stem cell gene expression," Annals of Biomedical Engineering, vol. 37, no. 3, pp. 492-502, 2009.

[100] A. M. Cribb and J. E. Scott, "Tendon response to tensile stress: an ultrastructural investigation of collagen: proteoglycan interactions in stressed tendon," Journal of Anatomy, vol. 187, no. 2, pp. 423-428, 1995.

[101] M. Chiquet, "Regulation of extracellular matrix gene expression by mechanical stress," Matrix Biology, vol. 18, no. 5, pp. 417-426, 1999.

[102] B. P. Flynn, A. P. Bhole, N. Saeidi, M. Liles, C. A. Dimarzio, and J. W. Ruberti, "Mechanical strain stabilizes reconstituted collagen fibrils against enzymatic degradation by mammalian collagenase matrix metalloproteinase 8 (MMP-8)," PLoS ONE, vol. 5, no. 8, Article ID el2337, 2010.

[103] N. Yamamoto, K. Ohno, K. Hayashi, H. Kuriyama, K. Yasuda, and K. Kaneda, "Effects of stress shielding on the mechanical properties of rabbit patellar tendon," Journal of Biomechanical Engineering, vol. 115, no. 1, pp. 23-28, 1993.

[104] E. Yamamoto, S. Tokura, N. Yamamoto, and K. Hayashi, "Mechanical properties of collagen fascicles from in situ frozen and stress-shielded rabbit patellar tendons," Clinical Biomechanics, vol. 15, no. 4, pp. 284-291, 2000.
[105] G. Yang, H.-J. Im, and J. H.-C. Wang, "Repetitive mechanical stretching modulates IL- $1 \beta$ induced COX-2, MMP-1 expression, and $\mathrm{PGE}_{2}$ production in human patellar tendon fibroblasts," Gene, vol. 363, no. 1-2, pp. 166-172, 2005.

[106] B. D. Hoffman, C. Grashoff, and M. A. Schwartz, "Dynamic molecular processes mediate cellular mechanotransduction," Nature, vol. 475, no. 7356, pp. 316-323, 2011.

[107] S. Li, Z. Ma, Z. Niu et al., "NASA-approved rotary bioreactor enhances proliferation and osteogenesis of human periodontal ligament stem cells," Stem Cells and Development, vol. 18, no. 9, pp. 1273-1282, 2009.

[108] S. Stich, Y. Ibold, A. Abbas et al., "Continuous cultivation of human hamstring tenocytes on microcarriers in a spinner flask bioreactor system," Biotechnology Progress, vol. 30, no. 1, pp. 142-151, 2014.

[109] J. M. Archambault, M. K. Elfervig-Wall, M. Tsuzaki, W. Herzog, and A. J. Banes, "Rabbit tendon cells produce MMP-3 in response to fluid flow without significant calcium transients," Journal of Biomechanics, vol. 35, no. 3, pp. 303-309, 2002.

[110] P. O. Bagnaninchi, Y. Yang, N. Zghoul, N. Maffulli, R. K. Wang, and A. J. El Haj, "Chitosan microchannel scaffolds for tendon tissue engineering characterized using optical coherence tomography," Tissue Engineering, vol. 13, no. 2, pp. 323-331, 2007.

[111] S. G. Kim, S.-G. Kim, B. Viechnicki, S. Kim, and H.-D. Nah, "Engineering of a periodontal ligament construct: cell and fibre alignment induced by shear stress," Journal of Clinical Periodontology, vol. 38, no. 12, pp. 1130-1136, 2011.

[112] M. Petri, C. Kruppa, C. Haasper et al., "Effects of continuous perfusion on human bone marrow stromal cells seeded on a decellularized bovine Achilles tendon matrix," Technology and Health Care, vol. 19, no. 4, pp. 223-231, 2011.

[113] K. H. Wenger, A. R. El-Awady, R. L. W. Messer, M. M. Sharawy, G. White, and C. A. Lapp, "Pneumatic pressure bioreactor for cyclic hydrostatic stress application: mechanobiology effects on periodontal ligament cells," Journal of Applied Physiology, vol. 111, no. 4, pp. 1072-1079, 2011.

[114] A. J. Banes, J. Gilbert, D. Taylor, and O. Monbureau, "A new vacuum-operated stress-providing instrument that applies static or variable duration cyclic tension or compression to cells in vitro," Journal of Cell Science, vol. 75, pp. 35-42, 1985.

[115] A. J. Banes, M. Tsuzaki, P. Hu et al., "PDGF-BB, IGF-I and mechanical load stimulate DNA synthesis in avian tendon fibroblasts in vitro," Journal of Biomechanics, vol. 28, no. 12, pp. 1505-1513, 1995.

[116] S. S. AbiEzzi, R. A. Foulk, F. L. Harwood, W. H. Akeson, and D. Amiel, "Decrease in fibronectin occurs coincident with the increased expression of its integrin receptor alpha5betal in stress-deprived ligaments," The Iowa orthopaedic journal, vol. 17, pp. 102-109, 1997.

[117] A. H. Hsieh, C. M.-H. Tsai, M. Qing-Jun et al., “Timedependent increases in type-III collagen gene expression in medial collateral ligament fibroblasts under cyclic strains," Journal of Orthopaedic Research, vol. 18, no. 2, pp. 220-227, 2000.

[118] T. Toyoda, H. Matsumoto, K. Fujikawa, S. Saito, and K. Inoue, "Tensile load and the metabolism of anterior cruciate ligament cells," Clinical Orthopaedics and Related Research, no. 353, pp. 247-255, 1998.

[119] M. Skutek, M. Van Griensven, J. Zeichen, N. Brauer, and U. Bosch, "Cyclic mechanical stretching modulates secretion pattern of growth factors in human tendon fibroblasts," European Journal of Applied Physiology, vol. 86, no. 1, pp. 48-52, 2001. 
[120] L. A. Matheson, N. J. Fairbank, G. N. Maksym, J. P. Santerre, and R. S. Labow, "Characterization of the Flexcell Uniflex cyclic strain culture system with U937 macrophage-like cells," Biomaterials, vol. 27, no. 2, pp. 226-233, 2006.

[121] A. Colombo, P. A. Cahill, and C. Lally, "An analysis of the strain field in biaxial Flexcell membranes for different waveforms and frequencies," Proceedings of the Institution of Mechanical Engineers H: Journal of Engineering in Medicine, vol. 222, no. 8, pp. 1235-1245, 2008.

[122] S.-G. Kim, T. Akaike, T. Sasagaw, Y. Atomi, and H. Kurosawa, "Gene expression of type I and Type III collagen by mechanical stretch in anterior cruciate ligament cells," Cell Structure and Function, vol. 27, no. 3, pp. 139-144, 2002.

[123] U. Nöth, K. Schupp, A. Heymer et al., "Anterior cruciate ligament constructs fabricated from human mesenchymal stem cells in a collagen type I hydrogel," Cytotherapy, vol. 7, no. 5, pp. 447-455, 2005.

[124] M. Lavagnino and S. P. Arnoczky, "In vitro alterations in cytoskeletal tensional homeostasis control gene expression in tendon cells," Journal of Orthopaedic Research, vol. 23, no. 5, pp. 1211-1218, 2005.

[125] N. Juncosa-Melvin, J. T. Shearn, G. P. Boivin et al., "Effects of mechanical stimulation on the biomechanics and histology of stem cell-collagen sponge constructs for rabbit patellar tendon repair," Tissue Engineering, vol. 12, no. 8, pp. 2291-2300, 2006.

[126] V. S. Nirmalanandhan, M. Rao, J. T. Shearn, N. Juncosa-Melvin, C. Gooch, and D. L. Butler, "Effect of scaffold material, construct length and mechanical stimulation on the in vitro stiffness of the engineered tendon construct," Journal of Biomechanics, vol. 41, no. 4, pp. 822-828, 2008.

[127] K. R. C. Kinneberg, V. S. Nirmalanandhan, N. Juncosa-Melvin et al., "Chondroitin-6-sulfate incorporation and mechanical stimulation increase MSC-collagen sponge construct stiffness," Journal of Orthopaedic Research, vol. 28, no. 8, pp. 1092-1099, 2010.

[128] V. S. Nirmalanandhan, J. T. Shearn, N. Juncosa-Melvin et al., "Improving linear stiffness of the cell-seeded collagen sponge constructs by varying the components of the mechanical stimulus," Tissue Engineering - Part A., vol. 14, no. 11, pp. 1883-1891, 2008.

[129] E. R. Jones, G. C. Jones, K. Legerlotz, and G. P. Riley, "Cyclical strain modulates metalloprotease and matrix gene expression in human tenocytes via activation of TGF $\beta$," Biochimica et Biophysica Acta-Molecular Cell Research, vol. 1833, no. 12, pp. 2596-2607, 2013.

[130] T. D. Nguyen, R. Liang, S. L.-Y. Woo et al., "Effects of cell seeding and cyclic stretch on the fiber remodeling in an extracellular matrix-derived bioscaffold," Tissue Engineering Part A, vol. 15, no. 4, pp. 957-963, 2009.

[131] R. I. Abousleiman, Y. Reyes, P. McFetridge, and V. Sikavitsas, "Tendon tissue engineering using cell-seeded umbilical veins cultured in a mechanical stimulator," Tissue Engineering Part A, vol. 15, no. 4, pp. 787-795, 2009.

[132] V. Vindigni, C. Tonello, L. Lancerotto et al., "Preliminary report of in vitro reconstruction of a vascularized tendonlike structure: a novel application for adipose-derived stem cells," Annals of Plastic Surgery, vol. 71, no. 6, pp. 664-670, 2013.

[133] J. D. Humphrey, P. B. Wells, S. Baek, J.-J. Hu, K. McLeroy, and A. T. Yeh, "A theoretically-motivated biaxial tissue culture system with intravital microscopy," Biomechanics and Modeling in Mechanobiology, vol. 7, no. 4, pp. 323-334, 2008.
[134] P. J. Yang, M. E. Levenston, and J. S. Temenoff, "Modulation of mesenchymal stem cell shape in enzyme-sensitive hydrogels is decoupled from upregulation of fibroblast markers under cyclic tension," Tissue Engineering Part A, vol. 18, no. 21-22, pp. 23652375, 2012.

[135] D. M. Doroski, M. E. Levenston, and J. S. Temenoff, "Cyclic tensile culture promotes fibroblastic differentiation of marrow stromal cells encapsulated in poly(ethylene glycol)-based hydrogels," Tissue Engineering A, vol. 16, no. 11, pp. 3457-3466, 2010.

[136] J. Lee, V. Guarino, A. Gloria et al., "Regeneration of Achilles' Tendon: the role of dynamic stimulation for enhanced cell proliferation and mechanical properties," Journal of Biomaterials Science, Polymer Edition, vol. 21, no. 8-9, pp. 1173-1190, 2010.

[137] Z. Feng, Y. Tateishi, Y. Nomura, T. Kitajima, and T. Nakamura, "Construction of fibroblast-collagen gels with orientated fibrils induced by static or dynamic stress: toward the fabrication of small tendon grafts," Journal of Artificial Organs, vol. 9, no. 4, pp. 220-225, 2006.

[138] I. Harada, S.-G. Kim, C. S. Cho, H. Kurosawa, and T. Akaike, "A simple combined floating and anchored collagen gel for enhancing mechanical strength of culture system," Journal of Biomedical Materials Research A, vol. 80, no. 1, pp. 123-130, 2007.

[139] X. Chen, Z. Yin, J.-L. Chen et al., "Force and scleraxis synergistically promote the commitment of human ES cells derived MSCs to tenocytes," Scientific Reports, vol. 2, article 977, 2012.

[140] J. Z. Paxton, P. Hagerty, J. J. Andrick, and K. Baar, “Optimizing an intermittent stretch paradigm using ERK1/2 phosphorylation results in increased collagen synthesis in engineered ligaments," Tissue Engineering A, vol. 18, no. 3-4, pp. 277-284, 2012.

[141] B. F. Jones, M. E. Wall, R. L. Carroll, S. Washburn, and A. J. Banes, "Ligament cells stretch-adapted on a microgrooved substrate increase intercellular communication in response to a mechanical stimulus," Journal of Biomechanics, vol. 38, no. 8, pp. 1653-1664, 2005.

[142] C. A. Bashur, R. D. Shaffer, L. A. Dahlgren, S. A. Guelcher, and A. S. Goldstein, "Effect of fiber diameter and alignment of electrospun polyurethane meshes on mesenchymal progenitor cells," Tissue Engineering Part A, vol. 15, no. 9, pp. 2435-2445, 2009.

[143] C. H. Lee, H. J. Shin, I. H. Cho et al., "Nanofiber alignment and direction of mechanical strain affect the ECM production of human ACL fibroblast," Biomaterials, vol. 26, no. 11, pp. 12611270, 2005.

[144] R. D. Cardwell, L. A. Dahlgren, and A. S. Goldstein, "Electrospun fibre diameter, not alignment, affects mesenchymal stem cell differentiation into the tendon/ligament lineage," Journal of Tissue Engineering and Regenerative Medicine, vol. 8, no. 12, pp. 937-945, 2014

[145] J. E. Moreau, D. S. Bramono, R. L. Horan, D. L. Kaplan, and G. H. Altman, "Sequential biochemical and mechanical stimulation in the development of tissue-engineered ligaments," Tissue Engineering_Part A, vol. 14, no. 7, pp. 1161-1172, 2008.

[146] Y. Qiu, J. Lei, T. J. Koob, and J. S. Temenoff, "Cyclic tension promotes fibroblastic differentiation of human MSCs cultured on collagen-fibre scaffolds," Journal of Tissue Engineering and Regenerative Medicine, 2014.

[147] S. Saber, A. Y. Zhang, S. H. Ki et al., "Flexor tendon tissue engineering: bioreactor cyclic strain increases construct strength," Tissue Engineering Part A, vol. 16, no. 6, pp. 2085-2090, 2010. 
[148] C. Y. L. Woon, A. Kraus, S. S. Raghavan et al., "Threedimensional-construct bioreactor conditioning in human tendon tissue engineering," Tissue Engineering A, vol. 17, no. 19-20, pp. 2561-2572, 2011.

[149] P. W. Whitlock, T. M. Seyler, C. N. Northam et al., "Effect of cyclic strain on tensile properties of a naturally derived, decellularized tendon scaffold seeded with allogeneic tenocytes and associated messenger RNA expression," Journal of surgical orthopaedic advances, vol. 22, no. 3, pp. 224-232, 2013.

[150] T. W. Qin, Y. Sun, A. R. Thoreson et al., "Effect of mechanical stimulation on bone marrow stromal cell-seeded tendon slice constructs: a potential engineered tendon patch for rotator cuff repair," Biomaterials, vol. 51, pp. 43-50, 2015.

[151] J. A. Hannafin, S. P. Arnoczky, A. Hoonjan, and P. A. Torzilli, "Effect of stress deprivation and cyclic tensile loading on the material and morphologic properties of canine flexor digitorum profundus tendon: an in vitro study," Journal of Orthopaedic Research, vol. 13, no. 6, pp. 907-914, 1995.

[152] M. Lavagnino, S. P. Arnoczky, T. Tian, and Z. Vaupel, "Effect of amplitude and frequency of cyclic tensile strain on the inhibition of MMP-1 mRNA expression in tendon cells: an in vitro study," Connective Tissue Research, vol. 44, no. 3-4, pp. 181187, 2003.

[153] K. Legerlotz, G. C. Jones, H. R. C. Screen, and G. P. Riley, "Cyclic loading of tendon fascicles using a novel fatigue loading system increases interleukin-6 expression by tenocytes," Scandinavian Journal of Medicine and Science in Sports, vol. 23, no. 1, pp. 31-37, 2013.

[154] T. A. L. Wren, D. P. Lindsey, G. S. Beaupré, and D. R. Carter, "Effects of creep and cyclic loading on the mechanical properties and failure of human Achilles tendons," Annals of Biomedical Engineering, vol. 31, no. 6, pp. 710-717, 2003.

[155] M. Lavagnino, A. Bedi, C. P. Walsh, E. R. S. Enselman, S. Sheibani-Rad, and S. P. Arnoczky, "Tendon contraction after cyclic elongation is an age-dependent phenomenon: in vitro and in vivo comparisons," The American Journal of Sports Medicine, vol. 42, no. 6, pp. 1471-1477, 2014.

[156] P. Eliasson, T. Andersson, and P. Aspenberg, "Influence of a single loading episode on gene expression in healing rat Achilles tendons," Journal of Applied Physiology, vol. 112, no. 2, pp. 279288, 2012.

[157] P. Eliasson, T. Andersson, M. Hammerman, and P. Aspenberg, "Primary gene response to mechanical loading in healing rat Achilles tendons," Journal of Applied Physiology, vol. 114, no. 11, pp. 1519-1526, 2013.

[158] P. Flecknell, "Replacement, reduction and refinement," ALTEX, vol. 19, no. 2, pp. 73-78, 2002.

[159] M. A. Machingal, B. T. Corona, T. J. Walters et al., "A tissueengineered muscle repair construct for functional restoration of an irrecoverable muscle injury in a murine model," Tissue Engineering-Part A, vol. 17, no. 17-18, pp. 2291-2303, 2011.

[160] C. A. Cook, P. Y. Huri, B. P. Ginn et al., "Bioreactor design for real-time conditioning and monitoring of tissue engineered muscle grafts," Tissue Engineering Part A, vol. 20, p. S38, 2014.

[161] M. S. M. Moritz, S. E. L. Verbruggen, and M. J. Post, "Alternatives for large-scale production of cultured beef: a review," Journal of Integrative Agriculture, vol. 14, no. 2, pp. 208-216, 2015.

[162] D. Gaspar, K. Spanoudes, C. Holladay, A. Pandit, and D. Zeugolis, "Progress in cell-based therapies for tendon repair," Advanced Drug Delivery Reviews, vol. 84, pp. 240-256, 2015.
[163] J. Burk, I. Ribitsch, C. Gittel et al., "Growth and differentiation characteristics of equine mesenchymal stromal cells derived from different sources," Veterinary Journal, vol. 195, no. 1, pp. 98-106, 2013.

[164] H. Tohyama and K. Yasuda, "Extrinsic cell infiltration and revascularization accelerate mechanical deterioration of the patellar tendon after fibroblast necrosis," Journal of Biomechanical Engineering, vol. 122, no. 6, pp. 594-599, 2000.

[165] C. N. Manning, N. Havlioglu, E. Knutsen et al., "The early inflammatory response after flexor tendon healing: a gene expression and histological analysis," Journal of Orthopaedic Research, vol. 32, no. 5, pp. 645-652, 2014.

[166] N. A. Dyment and J. L. Galloway, "Regenerative biology of tendon: mechanisms for renewal and repair," Current Molecular Biology Reports, vol. 1, no. 3, pp. 124-131, 2015. 

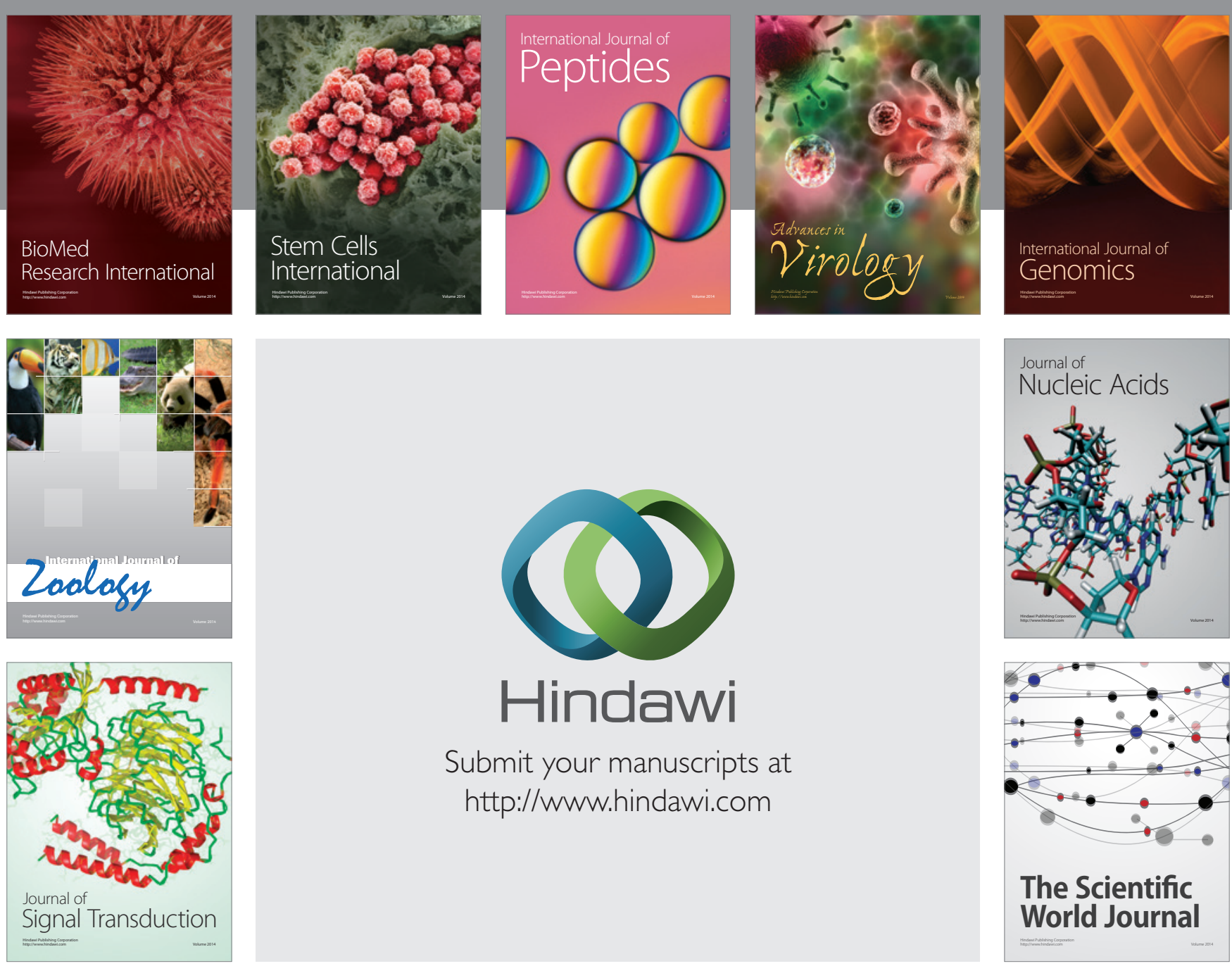

Submit your manuscripts at

http://www.hindawi.com
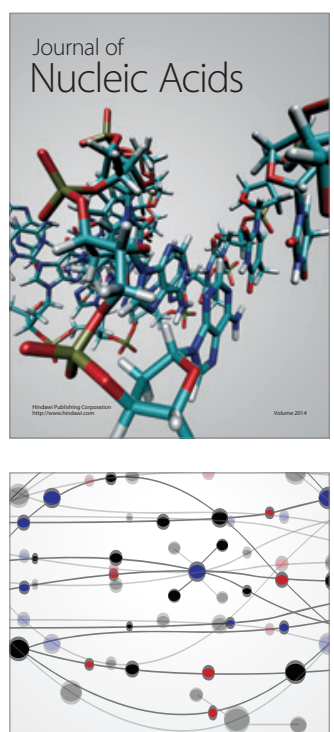

The Scientific World Journal
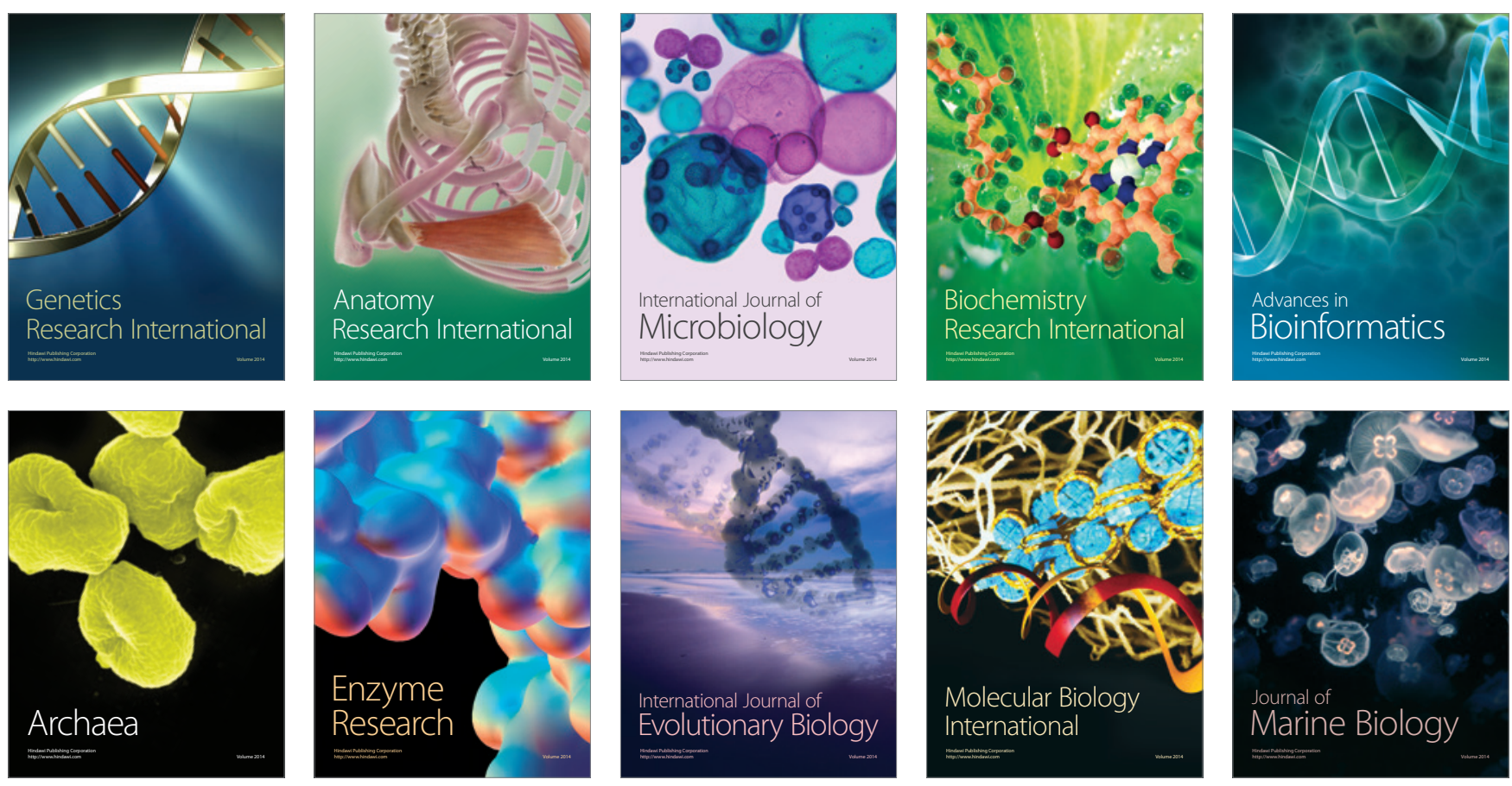